\title{
6. Instability and Stability in New Caledonia
}

\author{
Jean-Yves Faberon
}

\section{Instabilité et stabilité en Nouvelle-Calédonie}

Le préambule de l'Accord de Nouméa pose un principe de consensus par le biais du partage: «Le passé a été le temps de la colonisation. Le présent est le temps du partage, par le rééquilibrage. L'avenir doit être le temps de l'identité, dans un destin commun ». Si cette déclaration fut approuvée par les électeurs de Nouvelle-Calédonie au scrutin de novembre 1998 avec une majorité de $72 \%$, le chemin vers ce résultat commun a été long. Ce chapitre retrace l'histoire politique de la Nouvelle-Calédonie depuis 1853, dont le point culminant est l'Accord de Nouméa. Celui-ci, prenant en compte le passé colonial, rejette l'hypothèse selon laquelle l'indépendance pourrait intervenir brutalement et met en œuvre un calendrier de partage progressif des compétences en Nouvelle-Calédonie sur une durée de plus de 20 ans.

The preamble to the Noumea Agreement establishes a principle, namely consensus through sharing: 'The past was colonisation time. The present is the time for sharing and reaching a new balance. The future must be the time for an identity, in a common destiny.'

This statement, which is shot through with the spirit of sharing, was approved by voters in New Caledonia in the November 1998 election, with a 72 per cent majority. But the road to this common result has been a long one.

Even before the French landed in New Caledonia, Kanaks were far from being united. Their languages and their customs were different depending upon the area, and for that matter, their 'warrior traditions' are referred to in the Noumea Agreement.

With the arrival of the French, starting on 24 September 1853, the colonisation period started. It shook up the foundations of Kanak society and from a legal standpoint, it lasted over one century. That period was characterised by a very serious rift: the colonial society on the one hand and the indigenous society on the other hand, and they were totally separated, despite some individual exceptions. 
Politics, Development and Security in Oceania

With the IVth Republic, the new Constitution, in 1946, put an end to the colonial Empire, and the French Union was substituted for the colonial Empire. The Constitution's preamble abolished colonisation: 'France forgoes any colonial system based upon arbitrariness, France guarantees to all equal access to public employment and to the individual or collective exercise of rights and liberties.' It was not until 1956 that the Defferre law on the future of overseas territories actually implemented the new constitutional provision, and New Caledonia got a new status, through the July 1957 specific executive order.

The year 1953 saw the advent of a unique political organisation advocating a consensual New Caledonia - the Union Calédonienne. The Union Calédonienne's motto was: 'Two colors, one people'. With the 1957 status, this party gave New Caledonia its first Vice-President of the government council. He was a member of Parliament.

This consensus resoundingly translated into overwhelming support for the new French regime, the Vth Republic. General de Gaulle initiated a referendum vote on the new Constitution in September 1958, and the question was whether voters would choose to remain within the French Republic. Now, in New Caledonia at the time, there were more Kanaks than whites, and universal suffrage showed a 98 per cent yes vote.

General De Gaulle's government hardly showed any gratitude to New Caledonia for that almost unanimous vote. The government in Paris chipped away at New Caledonia's self-rule. The State advanced through the 1963 and 1965 Jacquinot laws and the 1969 Billotte laws. One of the Billotte laws dealt with mining regulations, and, precisely, 1969 was the start of a so-called 'Nickel boom', which lasted until 1972. That was an exhilarating growth period for New Caledonia's nickel resources. This unprecedented development operated across the board and impacted all the islands' activities; it attracted numerous groups of people from the motherland and from overseas territories. As a result, Kanaks were now a minority in their own land. They did not reap any profit from the new economic situation. Their country was a source of riches... except for them!

That period clearly coincides with the emergence of the breakaway movement. In 1969, the 'Red Scarves' were created by Nidoïsh Naisseline, the first Kanak to hold a college degree, and in 1971, Elie Poigoune created the '1978 Group'. As a result, in 1973, whites walked out of the Union Calédonienne party. In 1977, the Union Calédonienne joined the breakaway movement. The buzzword at the time was IKS, which means Kanak and Socialist Independence. It created an obstacle to consensus and to the communities' union. The Union Calédonienne's motto, 'one single people', effectively became obsolete. 
In September 1975, Jean-Marie Tjibaou, dealing more with the cultural than with the political ground, set up the 'Melanesia 2000' festival. This was to be followed by a more general festival called 'Caledonia 2000', dealing with the whole range of cultures present in New Caledonia. But the time was not ripe for it; the second festival never took place.

From then on, political forces started to line up for battle and not for the compact. Jacques Lafleur created the RPCR in 1978 under Tjibaou's presidency. Each of the two groups had its charismatic leader and was in battle order. The face-off did take place, and the 1980s were the painful and bloody decade: from the assassination of Pierre Declercq, the Union Calédonienne's Secretary General in September 1981, through the 21 deaths at the Ouvea cave in May 1988, to Tjibaou's assassination in 1989.

The 1980s, however, experienced a positive happening, an opportunity to work and be together, and that was the Nainville-les-Roches round table. In July 1983, amidst the conflict, Georges Lemoine, Under Secretary for Overseas Territories, a man who valued dialogue, brought together in Nainville-les-Roches representatives of various New Caledonia political attitudes, some seeking independence, such as Tjibaou, and some opposed to independence, such as Jacques Lafleur, along with representatives from the FNSC, the Federation for a new New Caledonian Society, who advocated a middle road. The meeting also included a representative of customary institutions.

The upshot of that meeting was a brief document containing the gist of the Noumea Accord! A few examples are:

- 'Definitely confirm that colonialism is dead...'

- 'Respect for all ethnic groups'.

- 'The necessity for a specific document with potential for adjustment to new situations...'

The RPCR, eventually, refrained from signing the statement... and this refusal led straight to what history has elected to call New Caledonia 'events'.

During those years, there was bloodshed in New Caledonia. On 24 September 1984, the Front Indépendantiste became the FLNKS, a name that was regarded by its opponents as a call to exclusion. The acronym FLNKS, along with the creation of a 'Provisional new government for the Republic', are clear references to the process that took place in Algeria, and which ended in disaster. So, very quickly, the situation proved to be a long way from the Nainville-les-Roches Declaration. 
Politics, Development and Security in Oceania

The status designed by the peace-loving Mr. Lemoine, dated September 6, 1984, was unanimously rejected, as all parties were raring to go, and naturally, tit calls for tat.

The French State appointed Edouard Pisani as government representative, as he seemed to be the right man for the job, since he was a socialist and formerly a long-time Gaullist minister. This political dualism was supposed to allow Pisani to create a link between the two political groups in New Caledonia. The plan he announced, however, and one he announced in a peremptory way, in January 1985, was unanimously rejected. Pisani's failure was as quick as his bursting upon the New Caledonian political scene, and not only did he fail to bring peace; he had to declare a state of emergency.

The rightist government, coming back into office in Paris in 1986, did not fare better in New Caledonia than its predecessor, and for the same reason: it did not act as an honest broker.

That led to the Ouvea massacre in April-May 1988.

Yet, there were history-making events. The new French government, under Michel Rocard, ultimately took an impartial stand, and wanted to solemnly restore peace on that basis. After having a mission called 'Dialogue Mission' analyze the situation on the field, the Prime Minister brought together Lafleur and Tjibaou and had them sign the Matignon Accords. The two partners finally agreed to fight for a common cause. And their gamble was a winner! Since 1988, New Caledonia has been in peace (even though Tjibaou was assassinated), and New Caledonia is on its way to the common destiny.

The genius of the Matignon-Oudinot Accords is that they divided New Caledonia into provinces. They succeeded, like a modern sphinx, in answering the question which had hitherto been left without an answer: How to allow breakaway factions, who are in the minority, to exert some kind of power in a majoritarian democracy? The answer consisted in dividing New Caledonia into three provinces where the respective majorities are different, so that both separatist factions and loyalists could have each a place where they were in the majority and where they could exercise power.

The genius of the Noumea Accord, which puts into perspective all the light and shadow of the past, lies in a gradual and pluralistic process. It is gradual in that it rejects the assumption that independence could occur suddenly, and it implements a schedule for power-sharing in New Caledonia spread over 20 years, one step at a time, so that at the end of the process, potential independence would not be like crossing over an unknown abyss, but only, for the whole population, a last step to add to those that had been taken already, and thus it would avert clashes and surprises. 
And the agreement is pluralistic in that it decides - and that is an exception which is the only one of its kind in the world - that New Caledonia would not be governed by a majority government but by a pluralistic government including representatives both of the majority and the minority (an 'opposition' which is in a peculiar situation). At any rate, the government is made up of representatives of separatists and loyalists in a sort of 'mandatory consensus'... This is a huge gamble for a model which is totally out of the ordinary, but it is working in New Caledonia. New Caledonia is now the place where what President N. Sarkozy stated on 22 June 2009 before the French Congress is being verified: 'A democracy where peace has been restored is not a democracy where there is general agreement but a democracy where people listen to each other and respect each other'.

Does that mean that after 20 peaceful and overall consensual years New Caledonia has shaken off its old demons? Of course not. Nobody can assert that the Noumea Accord gamble has been won in any definitive way. This agreement is a compromise between proponents of antagonistic attitudes as to the final relation of the islands to France. It has succeeded in bringing peace and spreading the common destiny mystique, which is a huge accomplishment, but eventually there remains to be seen (which the agreement does not do) whether this common destiny will be within or without France - although, of course, one can still hope for a solution in between, with France. Disagreements are certain to appear again, as in the issue of the definition of the Electorate or that of transfers of powers. People must be aware that when they base their action on a compromise basic document, which is inevitably ambiguous, disagreements are likely and natural. It is always important to face the problems, since by referring to disagreements with a sincere heart, we can make the Accord live on. For, in the final analysis, beyond pluralism and gradualism, beyond the fair memory of the colonial period that we mentioned, beyond the notions of citizenship and power transfer which undeniably make up the spirit of the agreement, what is the Noumea Accord? What gives the key to each of those components is respect for others, tolerance, the will for dialogue, and loyalty; this is the vital force of the Noumea Accord. Now these are components of human nature, and victory is never final on the dark side of human nature. Human nature is also made up of intolerance and the will to power. For this reason, there is no guarantee for success for the Noumea Accord. There simply is none. 